\title{
Biologists denounce UC role in funding start-up companies
}

San Francisco. Some of the most eminent biologists in the University of California (UC) system, including two Nobel laureates, believe that a university plan to fund start-up companies to exploit faculty inventions would be an expensive mistake.

In a letter sent on 8 March to UC president Jack W. Peltason, 43 leaders in molecular biology said the plan could seriously hurt the teaching, research and public service functions of the nine-campus system. They said existing technology transfer programmes have been successful and that there is no need for a complex, expensive new structure. Last week, Peltason told the UC board of regents that he will address faculty concerns before moving ahead.

The letter gave voice to growing faculty concern over a proposal from Peltason to boost UC royalties by setting up a for-profit Technology Development Company to develop faculty ideas into prototypes (see Nature 360, 701; 1992). The company, of which the university would own 51 per cent, would then license those products or form companies to commercialize them.

Many universities have aggressive technology transfer offices and take equity shares in start-ups, but few actually help to fund those ventures. The University of Chicago and Johns Hopkins University are among those that provide venture capital to prospective enterprises.

The University of California, operating in the heart of the \$6-billion US biotechnology industry, leads the nation's colleges in royalty income. It collected $\$ 29$ million for fiscal year 1992 and expects that figure to grow to $\$ 40$ million in the fiscal year ending this June.

Peltason sees the new corporation as a way to increase university revenues and to improve the state's sluggish economy, predicting that the expanded programme could produce $\$ 222$ million in gross royalty income by 2001 on operating costs of about $\$ 2$ million a year. The state, which normally claims about 15 per cent of the university's royalties, has promised to contribute its share to the enterprise.

But those who signed the letter say that the plan could end up costing the university money as well as diverting attention and resources from education. The plan would not change the inventors' share of royalty income but would centralize the technology transfer function. A separate proposal would give less royalty money to inventors but more to their departments and their own departmental accounts.

Paul Boyer, professor emeritus and retired founding director of UCLA's Molecular Biology Institute, who drafted the letter, says that the plan could undermine the university's traditional goals. He is concerned about a potential decrease in the authority of individual campuses, insufficient contact with faculty inventors and a loss of government and private support for university research.

"We don't need a university bureaucracy to do what industry already knows how to do", said Harold Varmus, who signed the letter along with J. Michael Bishop, with whom he shared the 1989 Nobel prize for medicine. "It suggests that the university is much more interested in making money than it ought to be."

Those who signed the letter are not opposed to commercializing discoveries made in UC laboratories - Varmus is a paid adviser to two biotechnology companies in California, Gilead and Onyx, while two others, Edward Penhoet and William Rutter, are respectively chief executive and chairman of Chiron Corporation. But they see the new UC company as blurring the distinction between the two sectors. "This is not a modest proposal", says Penhoet. "This is a proposal to get seriously involved in commercial business."

Sally Lehrman

\section{US meat inspections may get a strong dose of science}

Washington. The Clinton administration has promised to introduce modern microbiology into the $\$ 500$ million-a-year US Food Safety and Inspection Service (FSIS) in response to recent food scares, but it is not clear that the proposed reforms will proceed quickly enough to ensure effective monitoring and control of harmful microorganisms in the food chain.

The US agriculture secretary, Mike Espy, and the FSIS administrator, Russell Cross, have committed themselves to a two-stage programme that will first upgrade existing inspection procedures while preparing a science-based approach to counter recent outbreaks of food-poisoning, the most recent leading to the deaths this winter of three children in the northwestern United States after eating hamburgers contaminated by Escherichia coli 0157:H7.

The adoption of modern scientific methods would require a major transfer of resources within FSIS from the 7,500 inspectors towards research into both the application of existing monitoring techniques and the development of new ones. Major elements of the science-based programme would include the identification of critical control points in the food chain and the application of the latest advances in molecular biology, bioluminescence and biosensing. The programme, which was last week presented to a US House of Representatives agriculture subcommittee, would also set a microbiological baseline for

\section{IMAGE UNAVAILABLE FOR COPYRIGHT REASONS}

US inspectors check meat visually.

different classes of animals and would monitor the performance of slaughterhouses and food plants against that baseline.

But the fate of the programme is uncertain. FSIS says that the cost of microbial testing for 20 per cent of the meat supply could be as high as $\$ 58$ billion a year, and its seven-year timetable for implementation has led to concern that the agency may drag its feet in reforming an existing system, based on visual inspection of meat, that all agree is obsolete.

Congress intends to expedite matters by convening a meeting of interested parties, including scientists, federal agen-

cies and consumer groups, working under the supervision of a third party that would draw up binding proposals for reform. John McCutcheon, assistant administrator of FSIS, says that he "endorses the idea of such a public gettogether" but denies that such proposals are a criticism of the FSIS's own reform plans.

Prominent food scientists have expressed optimism that the FSIS proposals will lead to substantive change. "The administration is committed to these changes and that is the crux of the issue", says Michael Doyle, professor of food microbiology at the University of Georgia and a member of the Food and Nutrition Board of the US National Academy of Sciences that has reported frequently on the issue. Doyle estimates that the plan could mean tens of millions of dollars a year in additional research funds. Colin Macilwain 